\title{
A Novel Facile Method of Labeling Octreotide with ${ }^{18}$ F-Fluorine
}

Peter Laverman ${ }^{1}$, William J. McBride ${ }^{2}$, Robert M. Sharkey ${ }^{3}$, Annemarie Eek ${ }^{1}$, Lieke Joosten ${ }^{1}$, Wim J.G. Oyen ${ }^{1}$, David M. Goldenberg ${ }^{3}$, and Otto C. Boerman ${ }^{1}$

${ }^{I}$ Department of Nuclear Medicine, Radboud University Nijmegen Medical Centre, Nijmegen, The Netherlands; ${ }^{2}$ Immunomedics, Inc., Morris Plains, New Jersey; and ${ }^{3}$ Garden State Cancer Center, Center for Molecular Medicine and Immunology, Belleville, New Jersey

Several methods have been developed to label peptides with ${ }^{18} \mathrm{~F}$. However, in general these are laborious and require a multistep synthesis. We present a facile method based on the chelation of ${ }^{18} \mathrm{~F}$-aluminum fluoride $\left(\mathrm{Al}^{18} \mathrm{~F}\right)$ by $1,4,7$-triazacyclononane1,4,7-triacetic acid (NOTA). The method is characterized by the labeling of NOTA-octreotide (NOTA-D-Phe-cyclo[Cys-Phe-DTrp-Lys-Thr-Cys]-Throl $\left(\mathrm{MH}^{+}{ }^{+} 1305\right)$ [IMP466]) with ${ }^{18} \mathrm{~F}$. Methods: Octreotide was conjugated with the NOTA chelate and labeled with ${ }^{18} \mathrm{~F}$ in a 2-step, 1-pot method. The labeling procedure was optimized with regard to the labeling buffer, peptide, and aluminum concentration. Radiochemical yield, specific activity, in vitro stability, and receptor affinity were determined. Biodistribution of ${ }^{18} \mathrm{~F}$-IMP466 was studied in AR42J tumor-bearing mice and compared with that of ${ }^{68} \mathrm{Ga}$-labeled IMP466. In addition, small-animal PET/CT images were acquired. Results: IMP466 was labeled with $\mathrm{Al}^{18} \mathrm{~F}$ in a single step with $50 \%$ yield. The labeled product was purified by high-performance liquid chromatography to remove unbound $\mathrm{Al}^{18} \mathrm{~F}$ and unlabeled peptide. The radiolabeling, including purification, was performed in $45 \mathrm{~min}$. The specific activity was $45,000 \mathrm{GBq} / \mathrm{mmol}$, and the peptide was stable in serum for $4 \mathrm{~h}$ at $37^{\circ} \mathrm{C}$. Labeling was performed at $\mathrm{pH} 4.1$ in sodium citrate, sodium acetate, 4-(2-hydroxyethyl)-1piperazineethanesulfonic acid, and 2-( $N$-morpholino)ethanesulfonic acid buffer and was optimal in sodium acetate buffer. The apparent $50 \%$ inhibitory concentration of the ${ }^{19} \mathrm{~F}$-labeled IMP466 determined on AR42J cells was $3.6 \mathrm{nM}$. Biodistribution studies at $2 \mathrm{~h}$ after injection showed a high tumor uptake of ${ }^{18} \mathrm{~F}-$ IMP466 (28.3 \pm 5.2 percentage injected dose per gram [\%ID/ g]; tumor-to-blood ratio, $300 \pm 90$ ), which could be blocked by an excess of unlabeled peptide $(8.6 \pm 0.7 \% \mathrm{ID} / \mathrm{g})$, indicating that the accumulation in the tumor was receptor-mediated. Biodistribution of ${ }^{68} \mathrm{Ga}$-IMP466 was similar to that of ${ }^{18} \mathrm{~F}-\mathrm{IMP} 466$. ${ }^{18} \mathrm{~F}-\mathrm{IMP} 466$ was stable in vivo, because bone uptake was only $0.4 \pm 0.2 \% \mathrm{ID} / \mathrm{g}$, whereas free $\mathrm{Al}^{18} \mathrm{~F}$ accumulated rapidly in the bone $(36.9 \pm 5.0 \% \mathrm{ID} / \mathrm{g}$ at $2 \mathrm{~h}$ after injection). Small-animal $\mathrm{PET} / \mathrm{CT}$ scans showed excellent tumor delineation and high preferential accumulation in the tumor. Conclusion: NOTA-octreotide could be labeled rapidly and efficiently with ${ }^{18} \mathrm{~F}$ using a 2 -step, 1 -pot method. The compound was stable in vivo and showed rapid accretion in somatostatin receptor subtype 2-expressing

Received Jun. 3, 2009; revision accepted Nov. 16, 2009.

For correspondence or reprints contact: Peter Laverman, Department of Nuclear Medicine, Radboud University Nijmegen Medical Centre, P.O.

Box 9101, 6500 HB Nijmegen, The Netherlands.

E-mail: p.laverman@nucmed.umcn.nl

COPYRIGHT (c) 2010 by the Society of Nuclear Medicine, Inc.
AR42J tumors in nude mice. This method can be used to label other NOTA-conjugated compounds with ${ }^{18} \mathrm{~F}$.

Key Words: octreotide; radiofluorination; NOTA; peptide; PET; aluminum fluoride

J Nucl Med 2010; 51:454-461

DOI: 10.2967/jnumed.109.066902

\section{D} uring the past decade, radiolabeled receptor-binding peptides have emerged as an important class of radiopharmaceuticals that have changed radionuclide imaging. Peptides have been labeled with ${ }^{111} \mathrm{In}$ and ${ }^{99 \mathrm{~m}} \mathrm{Tc}$ for SPECT and, more recently, with positron emitters such as ${ }^{68} \mathrm{Ga},{ }^{64} \mathrm{Cu},{ }^{86} \mathrm{Y}$, and ${ }^{18} \mathrm{~F}$ for PET. ${ }^{18} \mathrm{~F}$ is the most widely used radionuclide in $\mathrm{PET}$ and has excellent characteristics for peptide-based imaging: the half-life $(110 \mathrm{~min})$ matches the pharmacokinetics of most peptides, and the low positron energy of $635 \mathrm{keV}$ results in short ranges in tissue and excellent preclinical imaging resolution $(<2 \mathrm{~mm})(1)$. A wide range of methods to label peptides with ${ }^{18} \mathrm{~F}$ have been investigated. In general, an ${ }^{18} \mathrm{~F}$-labeled synthon is produced by nucleophilic substitution, which is subsequently reacted with the functionalized peptide. One of the first generally applicable methods is based on conjugation of the synthon $N$-succinimidyl-4- ${ }^{18} \mathrm{~F}$-fluorobenzoate to a primary amino group of the peptide (2). Although widely used, the method requires a multistep synthesis and is, therefore, time-consuming and laborious. Poethko et al. have developed an improved ${ }^{18} \mathrm{~F}$-labeling method by reacting ${ }^{18} \mathrm{~F}$-fluorobenzaldehyde with an aminooxy-derivatized peptide, forming an oxime bond (3). Alternatively, ${ }^{18} \mathrm{~F}-$ fluorobenzaldehyde was reacted with hydrazine-nicotinamide-conjugated peptides. However, this method resulted in increased lipophilicity of the peptide that may lead to unfavorable characteristics in vivo (4). Carbohydration of the peptide may counteract the enhanced lipophilicity (5). More recently, ${ }^{18} \mathrm{~F}-\mathrm{FDG}$ was explored for the labeling of aminooxy-derivatized peptides $(6,7)$. This approach requires the use of carrier-free ${ }^{18} \mathrm{~F}-\mathrm{FDG}$, necessitating highperformance liquid chromatography (HPLC) purification of 
${ }^{18}$ F-FDG before conjugation with the functionalized peptide. Furthermore, methods based on the Huisgen cycloaddition of alkynes and azides were explored for the fluorination of peptides (8-11). Recently, silicon-based building blocks were used to fluorinate bombesin peptides functionalized with 2 tertiary butyl groups. However, this method also resulted in a lipophilic ${ }^{18} \mathrm{~F}$ peptide and loss of tumor targeting $(12,13)$.

We reported recently that a 1,4,7-triazacyclononane1,4,7-triacetic acid (NOTA)-conjugated pretargeting peptide could be labeled directly with ${ }^{18} \mathrm{~F}$ (14). To demonstrate that this 2-step, 1-pot method can be applied to other peptides, we report a new approach to label the somatostatin analog NOTA-octreotide with ${ }^{18} \mathrm{~F}$. Radiolabeled somatostatin analogs, such as diethylenetriaminepentaacetic acid (DTPA)-octreotide, DOTA-Tyr ${ }^{3}$-octreotide, NOTAoctreotide, and DOTA-Tyr ${ }^{3}$-octreotate, can be used to image somatostatin receptor subtype 2-expressing tumors. With this 2-step, 1-pot fluorination method, the peptide could be stably labeled with a $50 \%$ radiochemical yield at a high specific activity within $45 \mathrm{~min}$.

\section{MATERIALS AND METHODS}

\section{General}

The octreotide peptide analog NOTA-D-Phe-cyclo[Cys-Phe-DTrp-Lys-Thr-Cys]-Throl $\left(\mathrm{MH}^{+}\right.$1305), designated IMP466, was synthesized using standard Fmoc-based solid-phase peptide synthesis. After cleavage from the resin, the peptide was cyclicized by incubation with dimethyl sulfoxide overnight. The Throl resin and protected amino acids were purchased from CreoSalus Inc. The bis- $t$-butyl NOTA ligand was provided by Immunomedics, Inc. All other chemicals were purchased from Sigma-Aldrich or Fisher Scientific. All buffers used for the radiolabeling procedures were metal-free.

\section{Radiolabeling}

${ }^{18} \mathrm{~F}$ Labeling. The ${ }^{18} \mathrm{~F}$-labeling reaction is summarized in Figure 1. A QMA SepPak Light cartridge (Waters) with 2-6 GBq of ${ }^{18} \mathrm{~F}$ (BV Cyclotron VU) was washed with $3 \mathrm{~mL}$ of metalfree water. ${ }^{18} \mathrm{~F}$ was eluted from the cartridge with $0.4 \mathrm{M} \mathrm{KHCO}_{3}$, and fractions of $200 \mu \mathrm{L}$ were collected. The $\mathrm{pH}$ of the fractions was adjusted to 4 with $10 \mu \mathrm{L}$ of metal-free glacial acetic acid. Three microliters of $2 \mathrm{mM} \mathrm{AlCl}$ in $0.1 \mathrm{M}$ sodium acetate buffer, $\mathrm{pH} 4$, were added. Then, $10-50 \mu \mathrm{L}$ of IMP466 $(10 \mathrm{mg} / \mathrm{mL})$ were added in $0.5 \mathrm{M}$ sodium acetate, $\mathrm{pH}$ 4.1. The reaction mixture was incubated at $100^{\circ} \mathrm{C}$ for $15 \mathrm{~min}$ unless stated otherwise. The radiolabeled peptide was purified on reversed-phase (RP) HPLC. The ${ }^{18} \mathrm{~F}$-IMP466-containing fractions were collected and diluted 2-fold with $\mathrm{H}_{2} \mathrm{O}$ and purified on a 1-mL Oasis HLB cartridge (Waters) to remove acetonitrile and trifluoroacetic acid. In brief, the fraction was applied on the cartridge, and the cartridge was washed with $3 \mathrm{~mL}$ of $\mathrm{H}_{2} \mathrm{O}$. The radiolabeled peptide was then eluted with $2 \times 200 \mu \mathrm{L}$ of $50 \%$ ethanol. On injection in mice, the peptide was diluted with $0.9 \% \mathrm{NaCl}$.

\section{Effect of Buffer}

The effect of the buffer on the labeling efficiency of IMP466 with ${ }^{18} \mathrm{~F}^{-}$was investigated ( $n=3$ for each buffer). IMP466 was dissolved in sodium citrate buffer, sodium acetate buffer, 2-( $N$ morpholino)ethanesulfonic acid (MES) or 4-(2-hydroxyethyl)-1piperazineethanesulfonic acid (HEPES) buffer at $10 \mathrm{mg} / \mathrm{mL}(7.7$ $\mathrm{mM})$. The molarity of all buffers was $1 \mathrm{M}$, and the $\mathrm{pH}$ was 4.1 . To $200 \mu \mathrm{g}(153 \mathrm{nmol})$ of IMP466, $100 \mu \mathrm{L}$ of ${ }^{18} \mathrm{~F}$-aluminum fluoride $\left(\mathrm{Al}^{18} \mathrm{~F}\right)(\mathrm{pH} 4)$ were added and incubated at $100^{\circ} \mathrm{C}$ for $15 \mathrm{~min}$. Radiolabeling yield and specific activity were determined with RP HPLC as described below.

${ }^{68} \mathrm{Ga}$ Labeling. IMP466 was labeled with ${ }^{68} \mathrm{GaCl}_{3}$ eluted from a $\mathrm{TiO}_{2}$-based $1,110-\mathrm{MBq}{ }^{68} \mathrm{Ge} /{ }^{68} \mathrm{Ga}$ generator (Cyclotron Co. Ltd.) using 0.1 M HCl (Ultrapure; J.T. Baker). Five 1-mL fractions were collected, and an aliquot of the second fraction was used for labeling the peptide. IMP466 (4 $\mu \mathrm{g})$ was dissolved in $2.5 \mathrm{M}$ HEPES buffer, pH 7.0. ${ }^{68} \mathrm{Ga}$ eluate $(120-240 \mathrm{MBq}, 4$ times the volume of the peptide) was added, and the mixture was heated at $95^{\circ} \mathrm{C}$ for $20 \mathrm{~min}$. Then $50 \mathrm{mM}$ ethylenediaminetetraacetic acid was added to a final concentration of $5 \mathrm{mM}$ to complex the nonincorporated ${ }^{68} \mathrm{Ga}^{3+}$. The ${ }^{68} \mathrm{Ga}$-labeled IMP466 was purified on a $1-\mathrm{cm}^{3}$ Oasis HLB cartridge and eluted with $200 \mu \mathrm{L}$ of $50 \%$ ethanol. The specific activity of ${ }^{68} \mathrm{Ga}-\mathrm{IMP} 466$ was $20,000 \mathrm{GBq} /$ mmol at the time of injection.

\section{HPLC Analysis}

The radiolabeled preparations were analyzed by RP HPLC on an Agilent 1200 system (Agilent Technologies). A C18 column (Onyx monolithic, $4.6 \times 100 \mathrm{~mm}$; Phenomenex) was used at a flow rate of $2 \mathrm{~mL} / \mathrm{min}$ with the following buffer system: buffer $\mathrm{A}, 0.1 \%$ $\mathrm{v} / \mathrm{v}$ trifluoroacetic acid in water; buffer $\mathrm{B}, 0.1 \% \mathrm{v} / \mathrm{v}$ trifluoroacetic acid in acetonitrile; and a gradient of $97 \%$ buffer $\mathrm{A}$ at $0-5 \mathrm{~min}$ and $80 \%$ buffer A to $75 \%$ buffer $\mathrm{A}$ at $5-35 \mathrm{~min}$. The radioactivity of the eluate was monitored using an in-line NaI radiodetector (Raytest $\mathrm{GmbH}$ ). Elution profiles were analyzed using Gina-star software (version 2.18; Raytest $\mathrm{GmbH}$ ). The specific activity was determined by HPLC using calibration curves based on the ultraviolet signal.

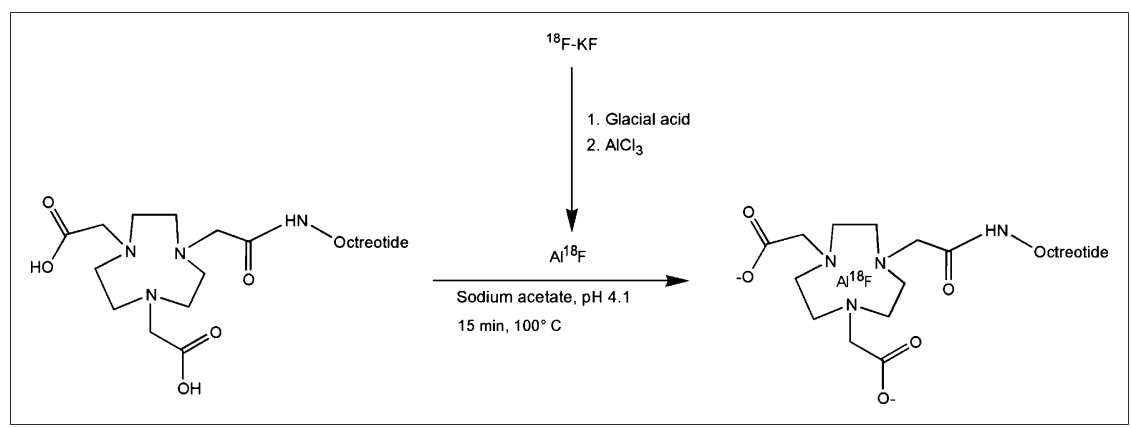

FIGURE 1. Preparation of $\mathrm{Al}^{18} \mathrm{~F}$ and chelation with NOTA-octreotide. 
Octanol-Water Partition Coefficient (log Poctanol/water)

To determine the lipophilicity of the radiolabeled peptides, approximately 50,000 counts per minute of the radiolabeled peptide were diluted in $0.5 \mathrm{~mL}$ of phosphate-buffered saline. An equal volume of 1-octanol was added to obtain a binary phase system. After stirring in a vortex mixer for $2 \mathrm{~min}$, we separated the 2 layers by centrifugation $(100 g, 5 \mathrm{~min})$. Three $100-\mu \mathrm{L}$ samples were taken from each layer, and radioactivity was measured in a well-type $\gamma$-counter (Wallac Wizard 3"; Perkin-Elmer).

\section{Stability}

Ten microliters of the ${ }^{18} \mathrm{~F}$-labeled IMP466 were incubated in $500 \mu \mathrm{L}$ of freshly collected human serum and incubated for $4 \mathrm{~h}$ at $37^{\circ} \mathrm{C}$. An equal volume of acetonitrile was added and stirred in a vortex mixer, then followed by centrifugation at $1,000 \mathrm{~g}$ for $5 \mathrm{~min}$ to pellet the precipitated serum proteins. The supernatant was analyzed on RP HPLC as described above.

The in vivo stability of ${ }^{18} \mathrm{~F}$-IMP466 was examined by injecting $18.5 \mathrm{MBq}$ of ${ }^{18} \mathrm{~F}$-IMP466 in a BALB/c nude mouse. After $30 \mathrm{~min}$, the mouse was euthanized, and blood and urine were collected and analyzed by HPLC.

\section{Cell Culture}

The AR42J rat pancreatic tumor cell line was cultured in Dulbecco's modified Eagle's medium (Gibco Life Technologies) supplemented with 4,500 mg of D-glucose per milliliter, $10 \%(\mathrm{v} / \mathrm{v})$ fetal calf serum, $2 \mathrm{mmol}$ of glutamine per liter, $100 \mathrm{U}$ of penicillin per milliliter, and $100 \mu \mathrm{g}$ of streptomycin per milliliter. Cells were cultured at $37^{\circ} \mathrm{C}$ in a humidified atmosphere with $5 \% \mathrm{CO}_{2}$.

\section{Apparent $50 \%$ Inhibitory Concentration $\left(\mathrm{IC}_{50}\right)$ \\ Determination}

The apparent $\mathrm{IC}_{50}$ for binding the somatostatin receptors on AR42J cells was determined in a competitive binding assay using ${ }^{19} \mathrm{~F}$-IMP466, ${ }^{69} \mathrm{Ga}$-IMP466, or ${ }^{115}$ In-DTPA-octreotide to compete for the binding of ${ }^{111}$ In-DTPA-octreotide (OctreoScan; Covidien).

${ }^{19} \mathrm{~F}-\mathrm{IMP} 466$ was formed by mixing an AlF solution $(0.02 \mathrm{M}$ $\mathrm{AlCl}_{3}$ in $0.5 \mathrm{M} \mathrm{NaAc}, \mathrm{pH}$ 4, with $0.1 \mathrm{M} \mathrm{NaF}$ in $0.5 \mathrm{M} \mathrm{NaAc}, \mathrm{pH} 4$ ) with IMP466 and heating at $100^{\circ} \mathrm{C}$ for $15 \mathrm{~min}$. The reaction mixture was purified by RP HPLC on a C- 18 column $(30 \times 150 \mathrm{~mm}$, Sunfire; Waters), as described above.

${ }^{69} \mathrm{Ga}$-IMP466 was prepared by dissolving gallium nitrate $(2.3 \times$ $\left.10^{-8} \mathrm{~mol}\right)$ in $30 \mu \mathrm{L}$ mixed with $20 \mu \mathrm{L}$ of IMP466 $(1 \mathrm{mg} / \mathrm{mL})$ in $10 \mathrm{mM} \mathrm{NaAc}, \mathrm{pH} 5.5$, and heated at $90^{\circ} \mathrm{C}$ for $15 \mathrm{~min}$. Samples of the mixture were used without further purification.

${ }^{115}$ In-DTPA-octreotide was made by mixing indium chloride $(1 \times$ $\left.10^{-5} \mathrm{~mol}\right)$ with $10 \mu \mathrm{L}$ of DTPA-octreotide $(1 \mathrm{mg} / \mathrm{mL})$ in $50 \mathrm{mM}$ $\mathrm{NaAc}, \mathrm{pH} \mathrm{5.5}$, and incubated at room temperature for $15 \mathrm{~min}$. This sample was used without further purification. ${ }^{111}$ In-DTPA-octreotide was radiolabeled according to the manufacturer's protocol.

AR42J cells were grown to confluency in 12-well plates and washed twice with binding buffer (Dulbecco's modified Eagle's medium with $0.5 \%$ bovine serum albumin). After $10 \mathrm{~min}$ of incubation at room temperature in binding buffer, ${ }^{19} \mathrm{~F}$-IMP466, ${ }^{69} \mathrm{Ga}$-IMP466, or ${ }^{115} \mathrm{In}$-DTPA-octreotide was added at a final concentration ranging from 0.1 to $1,000 \mathrm{nM}$, together with a trace amount $\left(10,000\right.$ counts per minute) of ${ }^{111}$ In-DTPA-octreotide (radiochemical purity $>95 \%$ ). After incubation at room temperature for $3 \mathrm{~h}$, the cells were washed twice with ice-cold phosphate-buffered saline. Cells were scraped, and cell-associated radioactivity was determined. Under these conditions, a limited extent of internaliza- tion may occur. Therefore, we describe the results of this competitive binding assay as apparent $\mathrm{IC}_{50}$ values rather than $\mathrm{IC}_{50}$. The apparent $\mathrm{IC}_{50}$ was defined as the peptide concentration at which $50 \%$ of binding without competitor was reached. Apparent $\mathrm{IC}_{50}$ values were calculated using GraphPad Prism software (version 4.00 for Windows; GraphPad Software).

\section{Biodistribution Studies}

Male nude BALB/c mice (6-8 wk old) were injected subcutaneously in the right flank with $0.2 \mathrm{~mL}$ of AR42J cell suspension of $1 \times$ $10^{7}$ cells $/ \mathrm{mL}$. Approximately $2 \mathrm{wk}$ after inoculation, when tumors were $5-8 \mathrm{~mm}$ in diameter, $370 \mathrm{kBq}$ of ${ }^{18} \mathrm{~F}$-labeled or ${ }^{68} \mathrm{Ga}$-labeled IMP466 (both $0.2 \mathrm{nmol}$ ) were administered intravenously $(n=5)$. Separate groups of mice $(n=5)$ were coinjected with a 1,000 -fold molar excess of unlabeled IMP466. One group of 3 mice was injected with unchelated $\mathrm{Al}^{18} \mathrm{~F}$. All mice were killed by $\mathrm{CO}_{2} / \mathrm{O}_{2}$ asphyxiation $2 \mathrm{~h}$ after injection. Tissues of interest were dissected, weighed, and counted in a $\gamma$-counter. The percentage injected dose per gram of tissue $(\% \mathrm{ID} / \mathrm{g})$ was calculated for each tissue on the basis of a dilution of the product for injection. The animal experiments were approved by the local animal welfare committee and performed according to national regulations.

\section{$\mathrm{PET} / \mathrm{CT}$}

Mice with subcutaneous AR42J tumors were injected intravenously with $10 \mathrm{MBq}$ of ${ }^{18} \mathrm{~F}-\mathrm{IMP} 466$ or ${ }^{68} \mathrm{Ga}$-IMP466 (both 0.7 $\mathrm{nmol})$ per mouse. One and $2 \mathrm{~h}$ after the injection of peptide, mice were scanned on an animal PET/CT scanner (Inveon; Siemens Preclinical Solutions) with an intrinsic spatial resolution of 1.5 $\mathrm{mm}(1)$. The animals were placed supine in the scanner. PET emission scans were acquired over $15 \mathrm{~min}$, followed by a CT scan for anatomic reference (spatial resolution, $113 \mu \mathrm{m} ; 80 \mathrm{kV}$, $500 \mu \mathrm{A})$. Scans were reconstructed using Inveon Acquisition Workplace software (version 1.2; Siemens Preclinical Solutions), using an ordered-set expectation maximization 3-dimensional maximum a posteriori algorithm with the following parameters: matrix, $256 \times 256 \times 159$; pixel size, $0.43 \times 0.43 \times 0.8 \mathrm{~mm}^{3}$; and $\beta$-value, 0.1 .

\section{Statistical Analysis}

All mean values are given as \pm SD. Statistical analysis was performed using a Welch's corrected unpaired Student $t$ test or 1way ANOVA using GraphPad InStat software (version 3.06; GraphPad Software). The level of significance was set at $P$ less than 0.05 .

\section{RESULTS}

\section{${ }^{18}$ F-Labeling Procedure}

HPLC analysis of the IMP466 labeling mixture (Fig. 2) showed the presence of unbound $\mathrm{Al}^{18} \mathrm{~F}$ (retention time $\left[\mathrm{R}_{\mathrm{t}}\right]=$ $0.8 \mathrm{~min})$ and 2 radioactive peptide peaks $\left(\mathrm{R}_{\mathrm{t}}=17.4\right.$ and 19.8 $\mathrm{min}$ ), indicating the formation of two ${ }^{18} \mathrm{~F}-\mathrm{IMP} 466$ stereoisomers. Moreover, an ultraviolet peak of unlabeled IMP466 is present $\left(R_{t}=21.4 \mathrm{~min}\right)$. After HPLC and HLB purification, both the unbound $\mathrm{Al}^{18} \mathrm{~F}$ and the unlabeled IMP466 ultraviolet peaks disappeared (Fig. 2).

Effect of Buffer. For sodium acetate, MES, or HEPES, the radiolabeling yield was $49 \% \pm 2 \%, 46 \% \pm 2 \%$, and $48 \% \pm 3 \%$, respectively ( $n=3$ for each buffer). In sodium citrate, no labeling was observed. When the labeling reaction was performed in sodium acetate buffer, the 


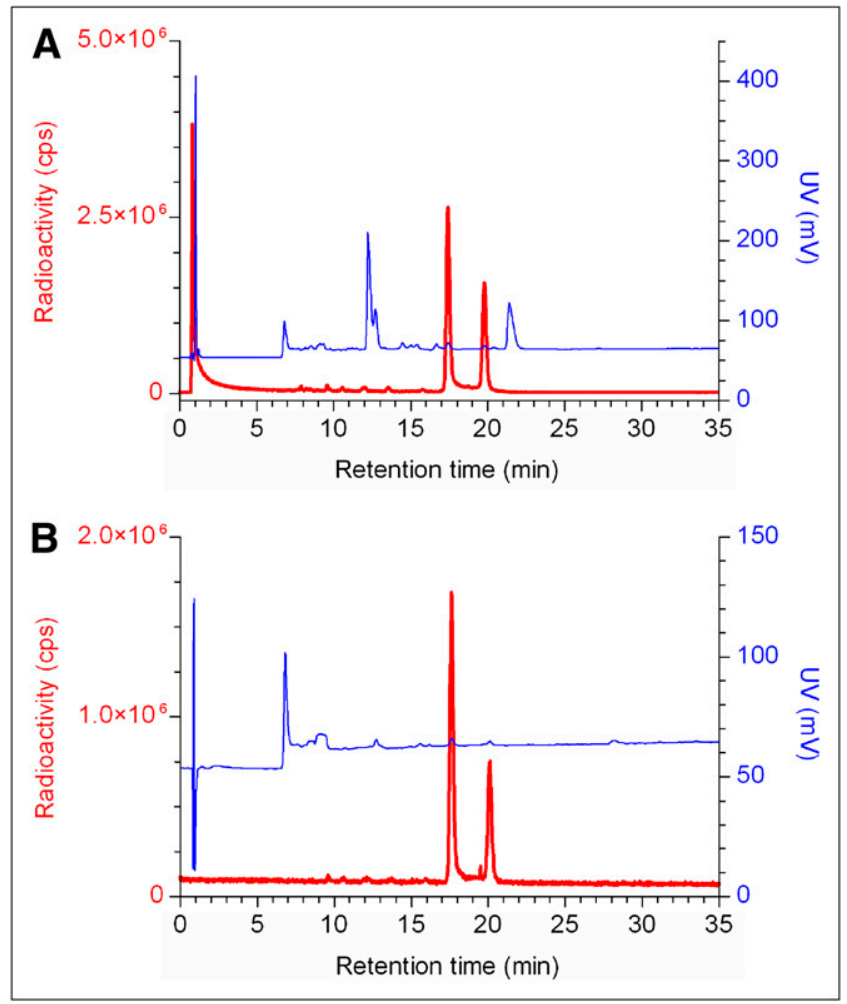

FIGURE 2. RP HPLC chromatograms of IMP466 ${ }^{18} \mathrm{~F}-$ labeling mix (A) and purified ${ }^{18} \mathrm{~F}$-IMP466 (B). Red traces represent radioactivity (left $y$-axis), and blue traces represent ultraviolet signal (right $y$-axis). In HPLC chromatogram of crude mixture, unbound $A{ }^{18} \mathrm{~F}$ eluted with void volume $\left(R_{t}=\right.$ $0.8 \mathrm{~min})$. Two radioactive peaks correspond to times of stereoisomers of radiolabeled peptide $\left(R_{t}=17.4\right.$ and 19.8 min). Finally, unlabeled IMP466 was present in ultraviolet channel $\left(R_{t}=21.4 \mathrm{~min}\right)$. After purification, only 2 radioactive peptide peaks are observed, indicating formation of 2 stereoisomers. $\mathrm{cps}=$ counts per second; UV $=$ ultraviolet.

specific activity was $32,000 \pm 17,000 \mathrm{GBq} / \mathrm{mmol}$, whereas in MES and HEPES buffer, specific activities of 29,000 \pm 14,000 and $31,000 \pm 23,000 \mathrm{GBq} / \mathrm{mmol}$, respectively, were obtained.

Effect of Peptide Concentration. The effect of peptide concentration on the labeling efficiency also was investigated. IMP466 was dissolved in sodium acetate buffer, $\mathrm{pH}$ 4.1 , at a concentration of $7.7 \mathrm{mM}(10 \mathrm{mg} / \mathrm{mL})$. Either 38 , 153 , or $363 \mathrm{nmol}$ of IMP466 were added to $200 \mu \mathrm{L}$ of $\mathrm{Al}^{18} \mathrm{~F}(581-603 \mathrm{MBq})$ to yield a final IMP466 concentrations of 190,765 , and $1,815 \mu \mathrm{M}$, respectively. The radiolabeling yield increased with increasing amounts of peptide. At a concentration of $190 \mu \mathrm{M}$, the radiolabeling yield was $8 \% \pm 1 \%$; at $765 \mu \mathrm{M}$, the yield increased to $42 \% \pm 3 \%$; and at the highest concentration, the radiolabeling yield was $50 \% \pm 2 \%$. The specific activity of the products obtained at each concentration was 48,000 $\mathrm{GBq} / \mathrm{mmol}$.

Effect of $\mathrm{AlCl}_{3}$ Concentration. Because $\mathrm{AlCl}_{3}$ is used to form $\mathrm{Al}^{18} \mathrm{~F}$, the added amount of $\mathrm{AlCl}_{3}$ is critical in the labeling procedure. Five stock solutions with various $\mathrm{AlCl}_{3}$ concentrations were prepared: $0.2,0.5,1.0,2.0$, and $20 \mathrm{mM}$. From these solutions in sodium acetate, 3 $\mu \mathrm{L}$ were added to $200 \mu \mathrm{L}$ of ${ }^{18} \mathrm{~F}$-fluoride, $\mathrm{pH} 4$, to form $\mathrm{Al}^{18} \mathrm{~F}$, resulting in final amounts of $\mathrm{AlCl}_{3}$ added of $0.6,1.5$, $3.0,6.0$, and $60 \mathrm{nmol}$, respectively. To these samples, 153 nmol of IMP466 (final concentration, $765 \mu \mathrm{M}$ ) were added and incubated for $15 \mathrm{~min}$ at $100^{\circ} \mathrm{C}$. Radiolabeling yield was optimal $(50 \% \pm 2 \%, n=5)$ after incubation with $6 \mathrm{nmol}$ of $\mathrm{AlCl}_{3}$. Lowering the $\mathrm{AlCl}_{3}$ concentration resulted in reduced yields, ranging from $42 \%$ at $3 \mathrm{nmol}$ to $10 \%$ at 0.6 nmol of $\mathrm{AlCl}_{3}$. Increasing the amount led to a similar effect. Incubation with $60 \mathrm{nmol}$ of $\mathrm{AlCl}_{3}$ resulted in a radiolabeling yield of only $6 \%$.

\section{Octanol-Water Partition Coefficient}

To determine the lipophilicity of the ${ }^{18} \mathrm{~F}$ - and ${ }^{68} \mathrm{Ga}-$ labeled IMP466, the octanol-water partition coefficients

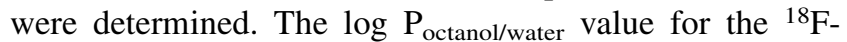
IMP466 was $-2.44 \pm 0.12$, and that of ${ }^{68} \mathrm{Ga}$-IMP466 was $-3.79 \pm 0.07$, indicating that the ${ }^{18}$ F-IMP466 was slightly less hydrophilic than ${ }^{68} \mathrm{Ga}$-IMP466.

\section{$\mathrm{IC}_{50}$ Determination}

The affinity profiles are shown in Figure 3 . The apparent $\mathrm{IC}_{50}$ of $\mathrm{Al}^{19} \mathrm{~F}$-labeled IMP466 was $3.6 \pm 0.6 \mathrm{nM}$, whereas that for ${ }^{69} \mathrm{Ga}$-labeled IMP466 was $13 \pm 3 \mathrm{nM}$. The apparent $\mathrm{IC}_{50}$ of the reference peptide, ${ }^{115}$ In-DTPA-octreotide (OctreoScan), was $6.3 \pm 0.9 \mathrm{nM}$.

\section{Stability}

${ }^{18} \mathrm{~F}$-labeled IMP466 did not release $\mathrm{Al}^{18} \mathrm{~F}$ after incubation in human serum at $37^{\circ} \mathrm{C}$ for $4 \mathrm{~h}$, indicating excellent stability of the $\mathrm{Al}^{18} \mathrm{~F}$-NOTA-octreotide. These findings were confirmed in vivo. After $30 \mathrm{~min}$, only intact radiolabeled

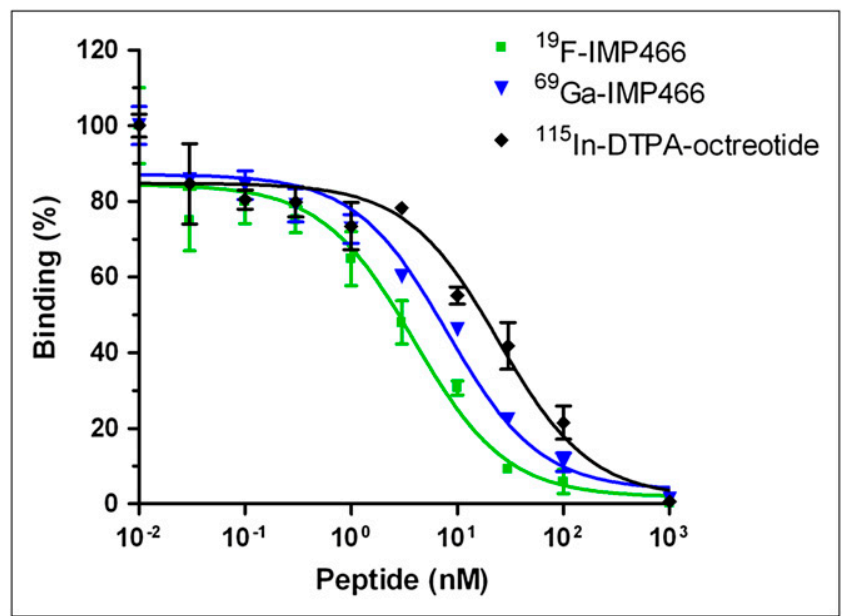

FIGURE 3. Competitive binding assay (apparent $\mathrm{IC}_{50}$ ) of ${ }^{19} \mathrm{~F}-I M P 466,{ }^{69} \mathrm{Ga}-I M P 466$, and ${ }^{115} \mathrm{In}$-DTPA-octreotide determined on AR42J tumor cells. Values on $y$-axis represent binding expressed as percentage of binding without competitor. 


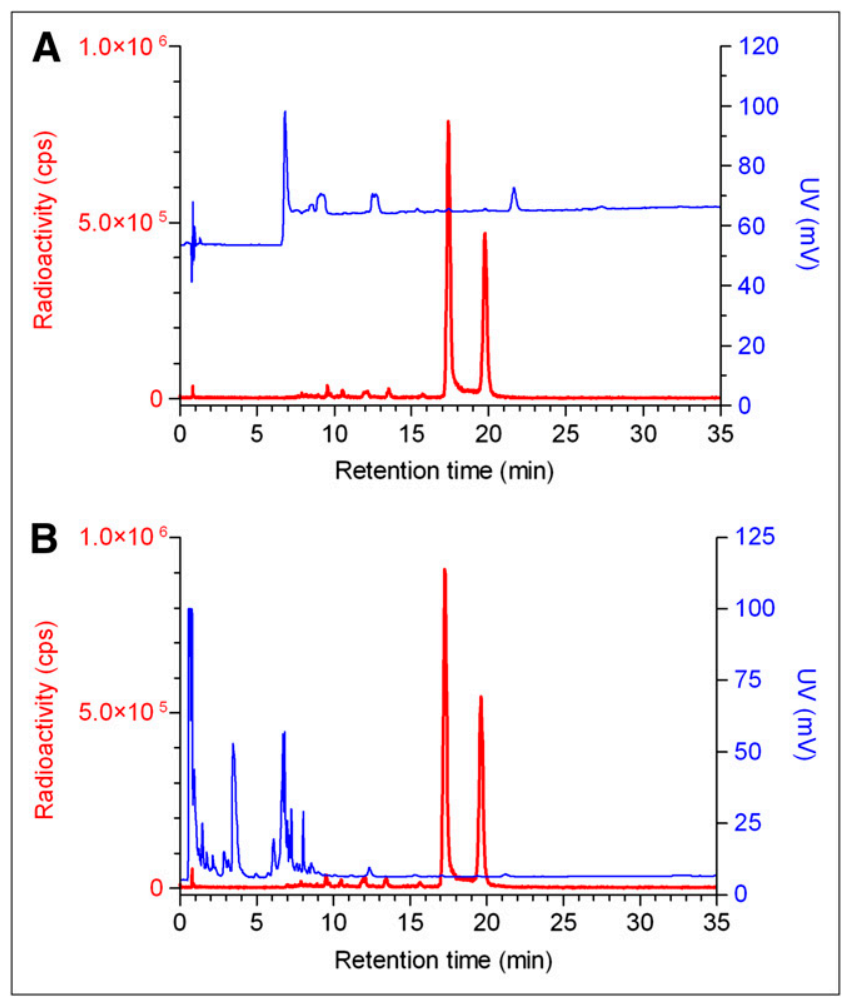

FIGURE 4. HPLC chromatograms of purified ${ }^{18} \mathrm{~F}-I M P 466$ before injection (A) and urine sample $30 \mathrm{~min}$ after injection (B). Red traces represent radioactivity (left $y$-axis), and blue traces represent ultraviolet signal (right $y$-axis). HPLC traces of 2 samples are similar, indicating that excreted product is intact ${ }^{18} \mathrm{~F}$-IMP466. $\mathrm{cps}=$ counts per second; UV = ultraviolet.

peptide was found in urine (Fig. 4) and no free ${ }^{18} \mathrm{~F}$. In addition, PET/CT scans did not reveal any bone uptake, indicating the absence of free ${ }^{18} \mathrm{~F}$-fluoride or $\mathrm{Al}^{18} \mathrm{~F}$.

\section{Biodistribution Studies}

The biodistribution of both ${ }^{18} \mathrm{~F}-\mathrm{IMP} 466$ and ${ }^{68} \mathrm{Ga}-$ IMP466 in BALB/c nude mice with subcutaneous AR42J tumors at $2 \mathrm{~h}$ after injection is summarized in Figures 5 and 6. Unchelated $\mathrm{Al}^{18} \mathrm{~F}$ was included as a control. Tumor uptake of ${ }^{18} \mathrm{~F}$-IMP466 was $28.3 \pm 5.7 \% \mathrm{ID} / \mathrm{g}$ at $2 \mathrm{~h}$ after injection and reduced in the presence of an excess of unlabeled IMP466 to $8.6 \pm 0.7 \% \mathrm{ID} / \mathrm{g}$, indicating that uptake was receptor-mediated. Nonspecific uptake of ${ }^{18} \mathrm{~F}$-IMP466 was somewhat higher than that of ${ }^{68} \mathrm{Ga}$-IMP466, as is illustrated by the less efficient blocking of the tumor uptake of ${ }^{18} \mathrm{~F}$ IMP466. Blood levels were low $(0.10 \pm 0.07 \% \mathrm{ID} / \mathrm{g}, 2 \mathrm{~h}$ after injection), resulting in a tumor-to-blood ratio of $300 \pm$ 90. Uptake in normal tissues, except in the kidneys, was low, with specific uptake in somatostatin receptor subtype 2expressing tissues, such as adrenal glands, pancreas, and stomach. Bone uptake of ${ }^{18} \mathrm{~F}$-IMP466 was negligible, as compared with uptake after injection of nonchelated $\mathrm{Al}^{18} \mathrm{~F}$ $(0.33 \pm 0.07 \% \mathrm{ID} / \mathrm{g}$ vs. $36.9 \pm 5.0 \% \mathrm{ID} / \mathrm{g}$ at $2 \mathrm{~h}$ after injection, respectively; $P<0.001$ ), indicating good in vivo stability of the ${ }^{18} \mathrm{~F}$-IMP466.

Tumor uptake of ${ }^{68} \mathrm{Ga}-\mathrm{IMP} 466(29.2 \pm 0.5 \% \mathrm{ID} / \mathrm{g}, 2 \mathrm{~h}$ after injection) was similar to that of ${ }^{18} \mathrm{~F}$-IMP466 $(P=$ 0.7). Lung uptake of ${ }^{68} \mathrm{Ga}$-IMP466 was 2-fold higher than that of ${ }^{18}$ F-IMP466 $(4.0 \pm 0.9 \% \mathrm{ID} / \mathrm{g}$ vs. $1.9 \pm 0.4 \% \mathrm{ID} / \mathrm{g}$, respectively). In addition, kidney retention of ${ }^{68} \mathrm{Ga}-\mathrm{IMP} 466$ was significantly higher than that of ${ }^{18} \mathrm{~F}-\mathrm{IMP} 466(16.2 \pm$ $2.86 \% \mathrm{ID} / \mathrm{g}$ vs. $10.0 \pm 1.3 \% \mathrm{ID} / \mathrm{g}$, respectively; $P<0.01)$.

Fused PET and CT scans are shown in Figure 7. PET scans largely corroborated the biodistribution data. Both ${ }^{18} \mathrm{~F}-\mathrm{IMP} 466$ and ${ }^{68} \mathrm{Ga}$-IMP466 showed high uptake in the tumor and high retention in the kidneys. The activity in the kidneys was localized mainly in the renal cortex. Some intestinal uptake was observed on the scans of ${ }^{18} \mathrm{~F}$-IMP466. The PET/CT scans also demonstrated that the $\mathrm{Al}^{18} \mathrm{~F}$ was stably chelated by the NOTA chelator, because no bone uptake was observed.

\section{DISCUSSION}

The radiolabeling of peptides with ${ }^{18} \mathrm{~F}$ involves laborious and time-consuming procedures and first requires the synthesis of an ${ }^{18} \mathrm{~F}$-labeled synthon. We showed recently that a NOTA-conjugated pretargeting peptide (IMP449) could be labeled with ${ }^{18} \mathrm{~F}$ in a 2-step, 1-pot reaction by creating $\mathrm{Al}^{18} \mathrm{~F}$ (14). Here, we describe the optimized ${ }^{18} \mathrm{~F}$-labeling of NOTAconjugated octreotide (IMP466) using the same approach. The biodistribution of the ${ }^{18} \mathrm{~F}$-NOTA-octreotide was compared with that of ${ }^{68} \mathrm{Ga}$-NOTA-octreotide. We demonstrated that the affinity of ${ }^{18} \mathrm{~F}-\mathrm{NOTA}$-octreotide was at least as good as that of ${ }^{111}$ In-DTPA-octreotide and was comparable with values reported in the literature for DOTA-octreotate and DOTA-D-Phe ${ }^{1}, \mathrm{Tyr}^{3}$-octreotide (15).

In the present study, we used the directly coupled NOTA derivative rather than the isothiocyanatobenzyl-derivatized NOTA to diminish the effect of the phenyl group on the lipophilicity of the peptide. For ${ }^{68} \mathrm{Ga}$ labeling, it has been demonstrated that this NOTA variant is as good as the isothiocyanatobenzyl-activated NOTA (16). After preparing the $\mathrm{A}{ }^{18} \mathrm{~F}$ complex, the chelation of this complex by NOTA was investigated in various buffers. We showed that chelation of $\mathrm{Al}^{18} \mathrm{~F}$ could be performed in sodium acetate, MES, and HEPES buffer, but, remarkably, the chelation failed in sodium citrate buffer. The labeling reaction requires fairly high NOTA-peptide concentrations. At the concentrations studied, the reaction was most efficient at an IMP466 concentration of $1.8 \mathrm{mM}$. This optimal concentration is in the same range as reported for other peptide fluorination methods $(3,4)$ but lower than the optimal concentration required in the classic $N$-succinimidyl-4- ${ }^{18} \mathrm{~F}$-fluorobenzoate method (2).

Subsequently, we investigated the effect of the amount of $\mathrm{Al}^{3+}$ on the radiolabeling yield. The $\mathrm{Al}^{3+}$ concentration greatly affects the labeling yield. First, the ${ }^{18} \mathrm{~F}^{-}$complexes with the $\mathrm{Al}^{3+}$, then the $\mathrm{Al}^{18} \mathrm{~F}$ complex is chelated by NOTA. After incubation at elevated temperature, the 


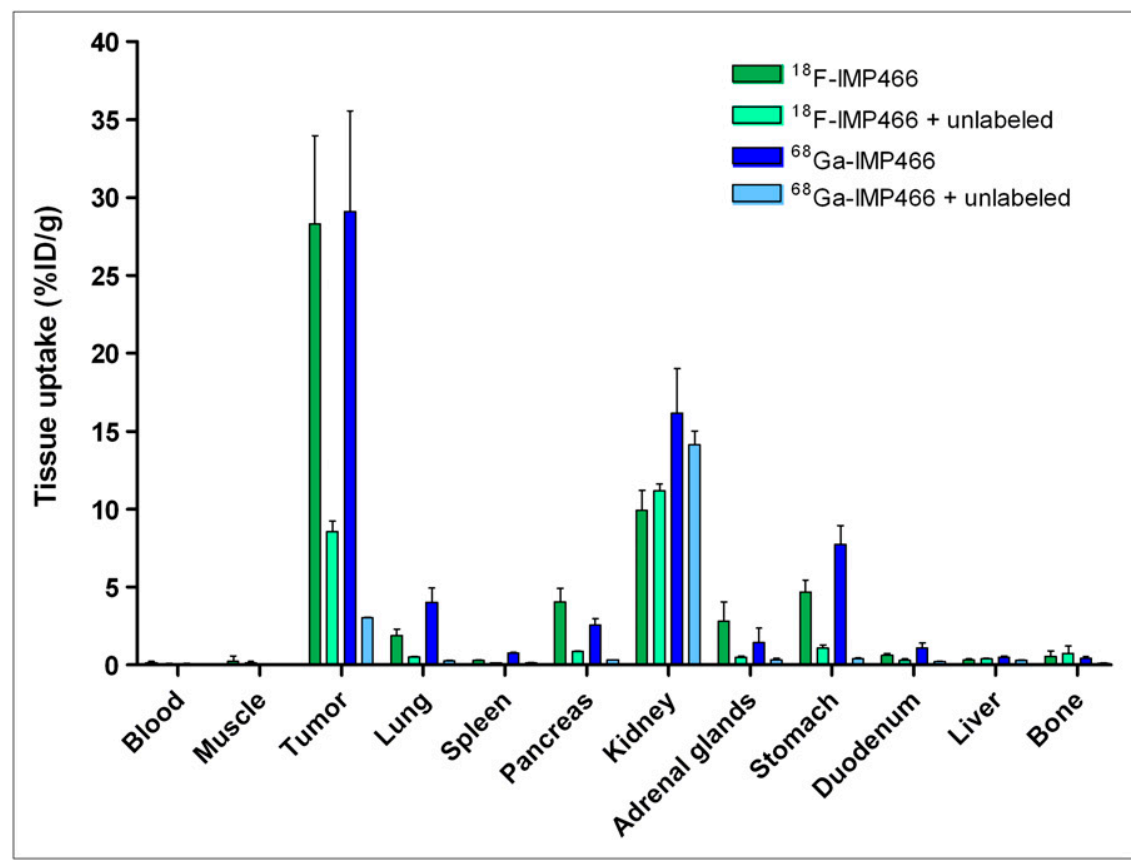

FIGURE 5. Biodistribution of ${ }^{18} \mathrm{~F}-$ IMP466 and ${ }^{68} \mathrm{Ga}-I M P 466$ at $2 \mathrm{~h}$ after injection in AR42J tumor-bearing mice ( $n=5$ /group). As control, mice in separate groups ( $n=3 /$ group) received excess of unlabeled octreotide to demonstrate receptor specificity. Tumors weighed $0.04-0.33 \mathrm{~g}$. reaction mixture is purified using HPLC to separate the $\mathrm{Al}^{18} \mathrm{~F}$-labeled IMP466 from unchelated $\mathrm{Al}^{18} \mathrm{~F}, \mathrm{Al}^{3+}$ labeled IMP466, and unlabeled IMP466. We showed that the optimal concentration of $\mathrm{AlCl}_{3}$ was $2 \mathrm{mM}$, whereas both at lower and at higher concentrations, the radiolabeling yield decreased. These data indicate that there is a delicate balance between ${ }^{18} \mathrm{~F}^{-}$and $\mathrm{Al}^{3+}$. Lowering the amount of $\mathrm{Al}^{3+}$ will lead to less ${ }^{18} \mathrm{~F}$ associated with $\mathrm{Al}^{3+}$. In contrast, a higher amount will yield more undesired NOTA-peptide labeled with $\mathrm{Al}^{3+}$ rather than labeled with $\mathrm{Al}^{18} \mathrm{~F}$. Because the formation of $\mathrm{Al}^{18} \mathrm{~F}$ is performed at $\mathrm{pH}$
4.1, we believe that the form of the aluminum in sodium acetate buffer is probably $\mathrm{Al}^{3+}\left(\mathrm{AcO}^{-}\right)_{3} \mathrm{~F}^{-}$. In any case, the molar ratio of aluminum to ${ }^{18} \mathrm{~F}$ is such that it is unlikely that any $\mathrm{AlF}_{2}$ or $\mathrm{AlF}_{3}$ is formed (17). We attempted to isolate the 2 isomers but observed that there was a rapid equilibrium between them. Therefore, no further studies of separate isomers were possible.

The lipophilicity of both the ${ }^{18} \mathrm{~F}$-labeled and the ${ }^{68} \mathrm{Ga}-$ labeled IMP466 was in the same range as reported for other ${ }^{111}$ In-labeled octreotide analogs (18). Other ${ }^{18} \mathrm{~F}$-labeled octreotide analogs, such as ${ }^{18} \mathrm{~F}$-fluoropropionyl octreotide

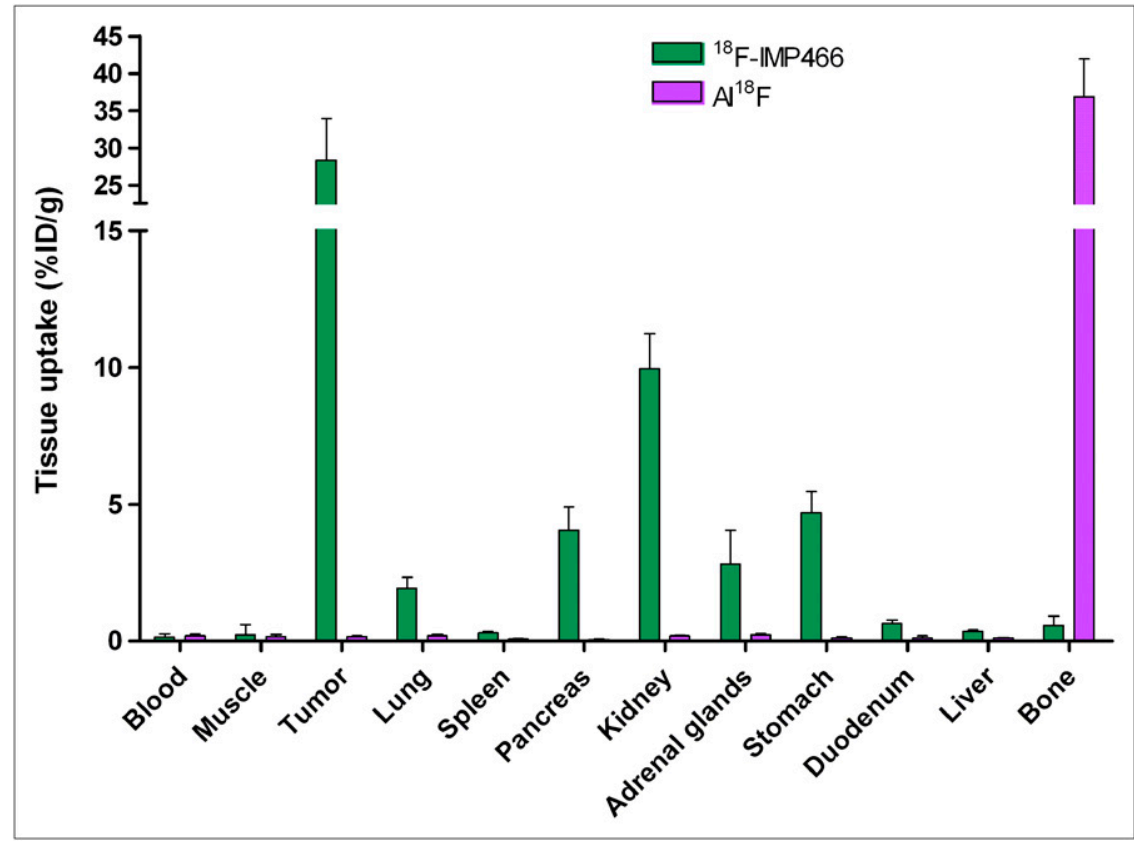

FIGURE 6. Biodistribution of ${ }^{18} \mathrm{~F}-$ IMP466 and unbound $\mathrm{Al}{ }^{18} \mathrm{~F}$ at $2 \mathrm{~h}$ after injection in AR42J tumor-bearing mice ( $n=5 /$ group). Tumors weighed $0.07-$ $0.36 \mathrm{~g}$. 

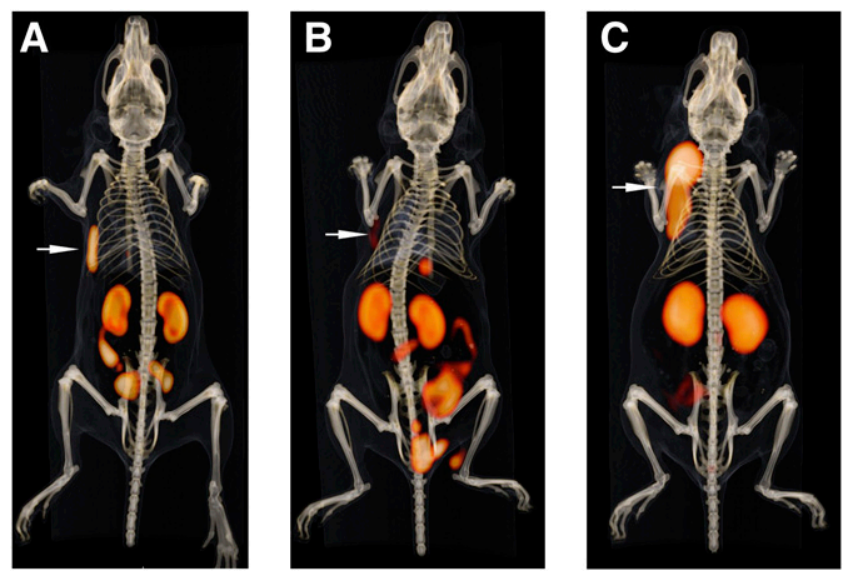

FIGURE 7. Anterior 3-dimensional volume-rendered projections of fused PET and CT scans of mice with subcutaneous AR42J tumor on right flank injected with ${ }^{18} \mathrm{~F}-I M P 466$ (A), ${ }^{18} \mathrm{~F}-I M P 466$ in presence of excess of unlabeled IMP466 (B), and ${ }^{68} \mathrm{Ga}-\mathrm{IMP} 466$ (C). Arrows indicate tumors. Scans were recorded at $2 \mathrm{~h}$ after injection.

$(\log \mathrm{P},-0.07 \pm 0.01)$ and $\mathrm{N}^{\alpha}$-(1-deoxy-D-fructosyl)- $\mathrm{N}^{\varepsilon_{-}}$ $\left(2-{ }^{18} \mathrm{~F}\right.$-fluoropropionyl)-Lys ${ }^{0}-\mathrm{Tyr}^{3}$ octreotate $\left({ }^{18} \mathrm{~F}-\mathrm{FP}-\mathrm{Gluc}-\right.$ TOCA) $(\log \mathrm{P},-1.70 \pm 0.02)$, displayed a higher lipophilicity (19). The biodistribution of ${ }^{18} \mathrm{~F}-\mathrm{FP}-G l u c-T O C A$ was similar to the biodistribution of ${ }^{18} \mathrm{~F}-\mathrm{IMP} 466$, but tumor uptake of the latter compound was 2-fold higher than that of the carbohydrate analog.

The biodistribution of ${ }^{18} \mathrm{~F}$-IMP466 was similar to that of ${ }^{68} \mathrm{Ga}$-IMP466, indicating that the $\mathrm{Al}^{18} \mathrm{~F}$ complex did not affect the in vivo characteristics of octreotide. Both peptides showed an equally high tumor uptake at $2 \mathrm{~h}$ after injection, with lower uptake in all other organs. The in vivo studies also showed the excellent stability of the $\mathrm{Al}^{18} \mathrm{~F}-\mathrm{NOTA}$ complex, because no significant bone uptake could be measured, and the intact product was isolated in the urine.

The current method can be performed in 1 pot, is fast ( 45 min), yields carrier-free fluorinated peptide, and does not affect the pharmacokinetics of octreotide. In most ${ }^{18} \mathrm{~F}-$ labeling strategies for peptides and proteins, a fluorinated synthon needs to be synthesized first. In general, this fluorination is based on a nucleophilic substitution that requires laborious azeotropic drying of the ${ }^{18}$ F-fluoridekryptofix complex. Examples of such a synthon are succinimidyl- ${ }^{18} \mathrm{~F}$-fluorobenzoate $(2), 4-{ }^{18} \mathrm{~F}$-fluorobenzaldehyde (3), and 2- ${ }^{18} \mathrm{~F}$-fluoropropionic acid 4-nitrophenyl ester (20). Subsequently, the synthon is reacted with the (functionalized) peptide, leading to longer synthesis times and lower overall yields. In addition, these techniques also lead to increased lipophilicity, because most synthons contain aromatic groups and this might affect the biodistribution profile. It has been reported that this effect can be counteracted by carbohydration (5). However, this requires considerable peptide modification.

More recently, a method based on silicon-fluorine has been published, in which the ${ }^{18} \mathrm{~F}$ is bound to a silicon- containing building block in a single step $(12,13)$. Although somewhat similar to our approach, the silicon $-{ }^{18} \mathrm{~F}$ initially proved to be unstable but could be stabilized by the addition of tertiary butyl groups. This, however, led to a strong increase in lipophilicity $(\log \mathrm{P}, 1.3 \pm 0.1)$.

Finally, click chemistry has been explored for the radiofluorination of peptides $(8-10)$. Although the yield of these click chemistry-based labeling procedures based on the alkyne-azide cycloaddition is excellent $(>80 \%)$, the method starts with the fluorination of an azide or alkyne, such as fluoro(ethyl)azide or a fluoroalkyne. This requires azeotropic drying of the fluoride, resulting in a time-consuming multistep procedure.

Compared with ${ }^{68} \mathrm{Ga}$ labeling, the $\mathrm{Al}^{18} \mathrm{~F}$ method is easy and versatile, mainly because both methods are based on a chelator-derivatized peptide. One of the advantages of the $\mathrm{Al}^{18} \mathrm{~F}$ method is the longer half-life of ${ }^{18} \mathrm{~F}$, allowing PET at later time-points after injection of the tracer.

\section{CONCLUSION}

Our new approach combines the ease of chelator-based radiolabeling methods with the advantages of ${ }^{18} \mathrm{~F}$ (i.e., halflife, availability, and positron energy). The F-labeled NOTA-octreotide could be synthesized in less than $45 \mathrm{~min}$ without the need to synthesize an ${ }^{18} \mathrm{~F}$ synthon. Moreover, the fluorinated peptide was stable in vitro and in vivo and has excellent tumor-targeting properties. Therefore, this fluorination method is a promising facile and versatile fluorination procedure.

\section{ACKNOWLEDGMENTS}

We thank Maarten Brom, Jonathan Disselhorst, and Bianca Lemmers-de Weem for technical assistance. This work was funded in part by NIH grant 1R43 EB00375101A1 from the National Institute of Biomedical Imaging and Bioengineering, Bethesda, Maryland. William J. McBride and David M. Goldenberg are employed or have financial interest in Immunomedics, Inc.

\section{REFERENCES}

1. Visser EP, Disselhorst JA, Brom M, et al. Spatial resolution and sensitivity of the Inveon small-animal PET scanner. J Nucl Med. 2009;50:139-147.

2. Lang L, Eckelman WC. One-step synthesis of ${ }^{18} \mathrm{~F}$ labeled $\left[{ }^{18} \mathrm{~F}\right]-\mathrm{N}$-succinimidyl 4(fluoromethyl)benzoate for protein labeling. Appl Radiat Isot. 1994;45:1155-1163.

3. Poethko T, Schottelius M, Thumshirn G, et al. Two-step methodology for highyield routine radiohalogenation of peptides: ${ }^{18} \mathrm{~F}$-labeled RGD and octreotide analogs. J Nucl Med. 2004;45:892-902.

4. Rennen HJ, Laverman P, van Eerd JE, Oyen WJ, Corstens FH, Boerman OC. PET imaging of infection with a HYNIC-conjugated LTB4 antagonist labeled with F-18 via hydrazone formation. Nucl Med Biol. 2007;34:691-695.

5. Schottelius M, Poethko T, Herz M, et al. First ${ }^{18} \mathrm{~F}$-labeled tracer suitable for routine clinical imaging of sst receptor-expressing tumors using positron emission tomography. Clin Cancer Res. 2004;10:3593-3606.

6. Hultsch C, Schottelius M, Auernheimer J, Alke A, Wester HJ. ${ }^{18} \mathrm{~F}-$ Fluoroglucosylation of peptides, exemplified on cyclo(RGDfK). Eur $\mathrm{J} \mathrm{Nucl}$ Med Mol Imaging. 2009;36:1469-1474.

7. Namavari M, Cheng Z, Zhang R, et al. A novel method for direct site-specific radiolabeling of peptides using $\left[{ }^{18}\right.$ F]FDG. Bioconjug Chem. 2009;2009;20:432436. 
8. Glaser M, Arstad E. "Click labeling" with 2-[18f]fluoroethylazide for positron emission tomography. Bioconjug Chem. 2007;18:989-993.

9. Hausner SH, Marik J, Gagnon MK, Sutcliffe JL. In vivo positron emission tomography (PET) imaging with an $\alpha_{\mathrm{v}} \beta_{6}$ specific peptide radiolabeled using ${ }^{18} \mathrm{~F}$ "click" chemistry: evaluation and comparison with the corresponding 4$\left[{ }^{18} \mathrm{~F}\right]$ fluorobenzoyl- and 2-[ $\left[{ }^{18} \mathrm{~F}\right]$ fluoropropionyl-peptides. J Med Chem. 2008;51: 5901-5904.

10. Marik J, Sutcliffe JL. Click for PET: rapid preparation of [F-18]fluoropeptides using Cu-I catalyzed 1,3-dipolar cycloaddition. Tetrahedron Lett. 2006;47:66816684.

11. Li ZB, Wu Z, Chen K, Chin FT, Chen X. Click chemistry for ${ }^{18} \mathrm{~F}$-labeling of RGD peptides and microPET imaging of tumor integrin $\alpha_{\mathrm{v}} \beta_{3}$ expression. Bioconjug Chem. 2007;18:1987-1994.

12. Hohne A, Mu L, Honer M, et al. Synthesis, ${ }^{18} \mathrm{~F}$-labeling, and in vitro and in vivo studies of bombesin peptides modified with silicon-based building blocks. Bioconjug Chem. 2008;19:1871-1879.

13. Mu L, Hohne A, Schubiger PA, et al. Silicon-based building blocks for one-step ${ }^{18} \mathrm{~F}$-radiolabeling of peptides for PET imaging. Angew Chem Int Ed Engl. 2008;47:4922-4925.
14. McBride WJ, Sharkey RM, Karacay $\mathrm{H}$, et al. A novel method of ${ }^{18} \mathrm{~F}$ radiolabeling for PET. J Nucl Med. 2009;50:991-998.

15. Reubi JC, Schar JC, Waser B, et al. Affinity profiles for human somatostatin receptor subtypes SST1-SST5 of somatostatin radiotracers selected for scintigraphic and radiotherapeutic use. Eur J Nucl Med. 2000;27:273-282.

16. Velikyan I, Maecke H, Langstrom B. Convenient preparation of ${ }^{68} \mathrm{Ga}$-based PETradiopharmaceuticals at room temperature. Bioconjug Chem. 2008;19:569-573.

17. Martin RB. Ternary hydroxide complexes in neutral solutions of $\mathrm{Al} 3+$ and $\mathrm{F}-$. Biochem Biophys Res Commun. 1988;155:1194-1200.

18. Antunes P, Ginj M, Walter MA, Chen J, Reubi JC, Maecke HR. Influence of different spacers on the biological profile of a DOTA-somatostatin analogue. Bioconjug Chem. 2007;18:84-92.

19. Wester HJ, Schottelius M, Scheidhauer K, et al. PET imaging of somatostatin receptors: design, synthesis and preclinical evaluation of a novel ${ }^{18} \mathrm{~F}$-labelled, carbohydrated analogue of octreotide. Eur J Nucl Med Mol Imaging. 2003;30:117-122.

20. Guhlke S, Wester HJ, Bruns C, Stocklin G. (2-[ $\left[{ }^{18} \mathrm{~F}\right]$ fluoropropionyl-(D)phe1)octreotide, a potential radiopharmaceutical for quantitative somatostatin receptor imaging with PET: synthesis, radiolabeling, in vitro validation and biodistribution in mice. Nucl Med Biol. 1994;21:819-825. 